\title{
IDENTIFICATION OF LACTOBACILLUS SPP. FROM BROILER LITTER IN BRAZIL
}

\author{
Ronaldo S. Paço ${ }^{1}$; Ivani Lucia Leme²; José Américo Bottino ${ }^{1}$; Antônio José Piantino Ferreira ${ }^{1 *}$ \\ ${ }^{1}$ Departamento de Patologia, Faculdade de Medicina Veterinária e Zootecnia, Universidade de São Paulo, São Paulo, SP, Brasil. \\ ${ }^{2}$ Departamento de Doenças Infecciosas e Parasitárias, Escola Paulista de Medicina, Universidade Federal de São Paulo, \\ São Paulo, SP, Brasil.
}

Submitted: May 05, 2003; Approved: September 01, 2003

\section{SHORT COMMUNICATION}

\begin{abstract}
Lactobacillus spp. were identified in 100 broiler litter samples collected from different poultry-rearing regions in Brazil. Ten different Lactobacillus species were identified: L. plantarum, L.casei subsp. pesudoplantarum, L. delbrueckii subsp. delbrueckii, L. reuteri, L. murinus, L. agilis, L. delbrueckii subsp. lactis, L. salivarus subsp. salicinus, $L$. viridenscens and $L$. amylophilus.
\end{abstract}

Key words: Lactobacillus spp., broiler litter, chicken.

Lactobacillus species are a bacterial group with morphologic, metabolic and physiologic common characteristics. They are Gram-positive, non-motile, non spore-forming, catalase negative, cytochrome absent, facultative anaerobes, aerotolerant, nutritionally demanding, acid-tolerant, with strictly fermentative metabolism, and lactic acid is the main product of carbohydrates fermentation (6). They are found in nutritionally rich habitats, such as milk, meat, vegetables, grains and in enteric normal microbiota from different animal species (2).

Studies on the intestinal bacteria and pathogen control by intestinal microbiota gained great interest in avian production in the last years (8). Avian enteric microbiota is formed according to the anatomic and physiologic characteristics conditions of the gastrointestinal tract. The microbial population on broiler litter is extremely diversified due to the continuous deposition of birds' excreta, secretions and desquamations. In this microenvironment, strict aerobes or anaerobes, and facultative anaerobes are the outstanding genera (7).

Lactobacillus colonizes avian enteric tract since the first day of life. These bacteria can colonize the small intestine of chicks, being ileum the segment with greater Lactobacillus diversity (5).

Broiler litter can be defined as vegetal material (wood, shaves, rice husk, coffee straw, sugar cane and other byproducts) that contains excreta (feces and urine), skin debris, feathers and feed residues (1). A "new" litter is the one that has not yet received production of birds, while the so-called "re-used" litter is that which has already received production of bird flocks once or more times.

The aim of this survey was to identify Lactobacillus spp. in broiler litter samples from different poultry-rearing regions in Brazil.

One hundred samples of broiler litters from nine poultryrearing areas in Brazil were used (Table 1). Each poultry-rearing farm sent 300 to $500 \mathrm{~g}$ of broiler litter collected in different points of the broiler houses. The samples were fractionated in $20 \mathrm{~g}$ packages and kept at $4^{\circ} \mathrm{C}$ in a sterile recipient.

Isolation of Lactobacillus species was carried out as follows: $5 \mathrm{~g}$ of each sample broiler litter were added to $50 \mathrm{ml}$ of MRS broth (Difco, Detroit, ML, USA) and kept at $37^{\circ} \mathrm{C}$ for 24 hours. Afterwards, the sample was grown on MRS agar and maintained at $37^{\circ} \mathrm{C}$ for 24 to 72 hours. Identification of bacteria was done as described byKlander and Weiss (6). The bacteria were lyophilized and kept at $-20^{\circ} \mathrm{C}$.

Out of the one hundred samples studied, twenty-three (23\%) Lactobacillus species were isolated: $L$. plantarum (39.1\%), $L$. casei subsp. pseudoplantarum (17.4\%), L. delbrueckii subsp. delbrueckii (8.7\%), L. reuteri (8.7\%), L. agilis (4.3\%), L. murinus

*Corresponding author. Mailing address: Av. Prof. Dr. Orlando Marques de Paiva, 87, Cidade Universitária. 05508-000, São Paulo, SP, Brasil. E-mail: ajpferr@usp.br 
Table 1. Results of Lactobacillus identification according to broiler litter samples in different poultry-rearing regions.

\begin{tabular}{|c|c|c|c|c|}
\hline Origin of litters & $\begin{array}{c}\text { Number of } \\
\text { broiler litter } \\
\text { samples } n=100\end{array}$ & $\begin{array}{l}\text { Lactobacillus identification } \\
\qquad \mathrm{n}=23\end{array}$ & $\begin{array}{l}\text { Kind of } \\
\text { broiler litter }\end{array}$ & $\begin{array}{l}\text { Indicator of } \\
\text { litter utilization }\end{array}$ \\
\hline São Paulo & 20 & L. plantarum $(2)^{*}$, L. murinus $(1)$ & Wood shaves & New \\
\hline Minas Gerais & 10 & L. plantarum (1), L. casei subsp. pseudoplantarum (4) & Wood shaves & New \\
\hline Santa Catarina & 16 & $\begin{array}{l}\text { L. plantarum (2), L. amilophilus (1) } \\
\text { L. plantarum (3), L. delbrueckii subsp. lactis (1), }\end{array}$ & Wood shaves & New \\
\hline Rio Grande do Sul & 22 & $\begin{array}{l}\text { L. salivarus subsp. salicinus (1), } \\
\text { L. delbrueckii subsp. delbrueckii (2), L. reuteri (2) }\end{array}$ & Wood shaves & Re-used 4x \\
\hline Paraná & 13 & L. plantarum (1) & Rice husk & New \\
\hline Mato Grosso & 5 & No isolation of Lactobacillus & Wood shaves & New \\
\hline Mato Grosso do Sul & 5 & L. agilis (1) & Rice husk & Re-used 5x \\
\hline Pernambuco & 4 & L. viridiensis (1) & Sugar cane byproducts & ts $\quad$ New \\
\hline Paraíba & 5 & No isolation of Lactobacillus & Rice husk & New \\
\hline
\end{tabular}

* Indicates the number of Lactobacillus isolates according to the sampled litters collected from each state.

(4.3\%), L. delbrueckii subsp. lactis (4.3\%), L. salivarus subsp. salicinius (4.3\%), L. viridenscens (4.3\%) and L. amylophilus $(4.3 \%)$.

Several factors may interfere on Lactobacillus viability in the litter, such as litter $\mathrm{pH}$, bird age, environmental temperature, state of re-use and others (3). In this study, the isolation of Lactobacillus species was not affected by the litter original kind, nor by the times the litter was reused (Table I).

The microbial population in broiler litter is highly diversified. Regarding the bacterial population on the enteric tract, Enterobacteriaceae, Lactobacillus, Micrococcus, Pseudomonas, Bacillus, Sarcinae, Clostridium and anaerobic bacteria are the main bacterial groups (3).

In this study, L. agilis, L. murinus and $L$. viridiensis were isolated from broiler litters. These species neither are commonly found in avian environments, nor in commercial birds' enteric tract, as some other Lactobacillus species, which are often isolated from avian gut. Therefore, their importance for the enteric microbiota balance, as well as their role in the development of intensively raised birds are being speculated(4).

These results showed the diversity of Lactobacillus species isolated in broiler litter samples obtained from different poultry-rearing areas in Brazil. Other studies should be carried out in order to better understand the importance of these species upon broiler intestinal microbiota regulation, reduction of ammonium in the shed, and their interference on the elimination of pathogens, such as Salmonella and Campylobacter $\mathrm{sp}$.

\section{ACKNOWLEDGEMENTS}

We are grateful to FAPESP for the financial support to this study (grants 97/3638 and 99/05087-8).

\section{RESUMO \\ Identificação de Lactobacillus spp sde cama de frango no Brasil}

Foram identificadas cepas de Lactobacillus spp. de 100 amostras de camas de frango coletadas de diferentes regiões de produção avícola do Brasil. Foram isoladas dez espécies diferentes de Lactobacillus: L. plantarum, L. casei subsp. pseudoplantarum, L. delbrueckii subsp. delbrueckii, L. reuteri, L. murinus, L. agilis, L.delbrueckii subsp. lactis, L. salivarus subsp. salicinus, L. viridenscens, L. amylophilus.

Palavras-chave: Lactobacillus spp., cama de frango, frango.

\section{REFERENCES}

1. Avila, V.S. Cama de aviário: materiais, reutilização uso como alimento e fertilizante. Embrapa. 1992. 38 f. circular técnica, 16.

2. Axelson, L.T. Lactic Acid Bacteria. In: Salminem, S.; Von Wright, A. (eds). Lactic Acid Bacteria: microbiology and functional aspects. New York, Marcel Dekker, 1998. p.234-257.

3. Halbrook, E.R.; Winter, A.R.; Sutton, T.S. The microflora of poultry house litter and droppings. Poult. Sci., 30:381-388, 1951.

4. Hartemink, R.; Domenech, V.R.; Rombouts, F.M. LAMVAB- A new selective medium for the isolation of Lactobacilli from faeces. $J$. Microbiol. Methods, 29:77-84, 1997.

5. Jin, L.Z.; Abdullah, N.; Ali, M.A.; Jalaludin, S. Antagonistic effects of intestinal Lactobacillus isolates on pathogens of chicken. Lett. Appl. Microbiol., 23:67-71, 1996.

6. Klander, O.; Weiss, N. Regular, Nonsporing Gram-Positive Rods In: Sneath, P.H.A.; Mair, N.S.; Sharpe, M.E.; Holt, J.G. (eds). Bergey's Manual of Systematic Bacteriology. Williams and Wilkins, Baltimore, 1986, p.1208-1234.

7. Medeiros, A.A.; Schocken-Iturrino, R.P.; Berchieri Jr, A; Sorbara, J.O.; Ronchi, C.P.H. Estirpes de Lactobacillus sp isoladas de fezes de aves para utilização como probiótico. Conferência Apinco de Ciência e Tecnologia Avícolas, São Paulo, 1998, p.42.

8. Stavric, S. Defined cultures and prospects. Int. J. Food Microbiol., 15:245-63, 1992 